\title{
Excavation of History and Narration of Subaltern Orality in the Short Stories of Mahasweta Devi
}

\author{
Anuranj C K \\ Assistant Professor \\ India \\ anuranjblathur@gmail.com
}

\begin{abstract}
In 1979 Mahasweta Devi had written and published a short story collection in Bengali language. Later, the short story collection had been translated into English by Ipsita Chanda and published in 1998 under the title of Bitter Soil. This paper studies two short stories from this collection of translation, which entitled as Little Ones and Salt respectively. Mahasweta Devi made tremendous contribution to literary, social and cultural studies in this country and she always believed that the real history is made by the ordinary people as she is also a political activist. Both these short stories represent the history of post independent India. Mahasweta Devi's empirical research into oral history and haunting tales of exploitation and struggle as it lives in the cultures and reminiscences of tribal communities is highly relevant today.

Keyword: Adiwasis, Aagariya tribes, under priviledged, down-trodden, excavation, subaltern orality.

In the introductory part of Bitter Soil, Mahasweta Devi opens up her intention to be a historicist of Palamau, the tribal village forest which leads us to the same idea that recording the history of the Subaltern.
\end{abstract}


I believe in documentation. After reading my work, the reader should face the truth of facts, and feel duly ashamed of the true face of India. To fully understand these stories, one must have a knowledge of agricultural economy and land-relations; because caste and class exploitation and the resistance of the exploited ones are rooted in India's land system. I say 'India', though the location of these stories is Palamau.” (Bitter Soil) Unless and until the indigenous Indian records their myths and folk tales, we the 'other' won't recognise them as literature or history, nor the non tribes hardly ever think of it. The contemporary subaltern Indian literature is not able to record their facts and their precious literature due to many reasons. Therefore, Mahasweta Devi's deliberate attempt towards recording tribal history is as important as the development of subaltern studies. Tribal culture and orality are articulated by Mahasweta Devi in almost all the works and as a roaming reporter in the region inhabited by indigenous tribes, she always depicted police misconduct, incompetence of the authorities, mistakes and malpractices during the implementation of governmental aids and assistance programmes.

Mahasweta Devi has a political intention to write contemporary history of Adivasis and tribal villages. In Salt, she narrates, "In those days like today, it was very easy to buy land and drive out the Adivasis. Adivasis then were as wary as they are today of accounts-documentsdeeds-laws." (125 salt)Nothing is changed or nothing is progressed around the subaltern lives even after India got independence. The history of India cannot be written unless we consider the colonial background of India. Simultaneously, the contemporary history of India cannot be written unless we consider postcolonial conditions of the subaltern, especially the tribal and indigenous community which the short story Salt unfolds ostensibly. 
As far as the colonial Indian history is concerned, salt is the symbol of resistance and struggle. Salt is metaphor for British oppression and exploitation when British colonisers forbid the making of salt and compelled Indians to purchase imported salt. It is perspicuous to put salt with flavour that makes all food palatable and that has been universally highly valued from ancient times in India. When this symbolism is applied to Devi's stories about the outcasts and the oppressed of the indigenous tribes of India like dalits, proletariats and adivasis, her stories speak of love that these rejected ones deserve and that must be portrayed through equitable political, social and economic advantages.

As story develops, Uttamchand, the feudal comprador in Salt takes revenge upon Purti Munda and other people in the village and explains his agenda that "I'll kill them by salt." $(\mathrm{BS}, 128)$. Here, salt is a metaphor for a larger political activity and the rest of the story is the continuation of that revenge, the unavailability of salt from the upcoming days in the tribal market shows us the external intervention from outside of the village is dropped them into an utter disaster. In the end of the story Devi declares that

"the apparent truth is that the elephant ekoa died because it killed Purti and the others. But the underlying truth seems to be something else. All this because of mere salt! They couldn't get the salt. If they could buy the salt, three men and one elephant would still alive, someone else was responsible, someone else. The person who would not sell the salt? Or some other law? Some other system?"

Coloniser's external power is merged with native's internal power. During the time of colonial invasion, the structure of power hierarchy in India was unquestionably dominated by the domestic Indian land lords. I would like to clarify this by noting that whoever the colonisers be, they, at first searched for the internal power holders. Unfortunately there was no resistance or 
counter attack from the elite ruling class, all struggles occurred against colonialism had been done by subaltern or working class men. Actually colonisers were well utilising the "power". Therefore, the insertion of India into colonialism can be defined as a change from feudalism into capitalist subjection. It was the vigorous politicization and democratization that we have been claiming for a long period.

When looking at the colonial history of India, our consciousness will urge us to be an extreme national as well as exhort us to work for the nation inhumanly. Meanwhile looking at the postcolonial history or contemporary history of India we are unimaginably perplexed by the situation of subaltern. How can subaltern be an extreme national unless the nationalists stop their colonisation upon subaltern? The short story Little Ones is an unusual narrative which describes the unsettling encounter between the relief officer and the Aagariyan tribe in a famine stuck village. This relief officer is named Mr Singh who has been sent to help and, in long term rehabilitate the tribal. The story is also a social documentary where Mahasweta Devi tried to describe lack of nutrition and starvation has done to human body. As Mahasweta Devi says, "Starvation over generations can reduce ordinary- sized human beings to pygmies". This is exactly what happens in the story, the "little ones", who are described as supernatural kids are in reality adult Aagariya, shrunk in size. From the beginning of the story, the Aagariya tribe is described by the government officials as "uncivilized", "jungle" and who have "no honest way of living".

In response to the question, "What would you like to do for the rest of your life?" in a 1998 interview, Mahashweta Devi replied, "Fight for the tribes, downtrodden, underprivileged and write creatively if and when I find the time".National narratives, orientalist images, ethnic stereotypes, and Hindu majoritarianism are highly influential in subaltern studies and Mahasweta 
Devi is stridently critical against especially Hindu majoritarianism and ridicules at Brahmanical greed says in Little Ones that "they combed the jungle like a Brahmin widow picks worm from rice.”(6,Bitter Soil)

We get to know from the conversation between the BOD and the relief officer that professionally the tribe were iron miners who have been given barren land for cultivation. Their traditional profession has been taken away from them and forced to work as farmers on barren land. The topography of the region is vividly described by Mahasweta Devi and she stresses that the area is "burnt- out desert" so evidently even if the tribal are given land, they won't be able to cultivate. But the BOD suggests that it is the tribal who lack incentive to cultivate the land and find reasons to sell it off.

In the narrative the Government and their officials are shown as insensitive towards tribe and their culture. They take over their land in order to extract iron. The blast of the hillock by the officials makes the Aagariyas outrageous. They kill the officials and flee to the dense forest in a way that they never found. The protest is the result of taking away of the land and the government reciprocates it by burning down the village and heavily taxing the remaining villages. The relief officer who come to the village have a romanticized image of the tribal, “adivasi men play the flute and adivasi women dance with flowers in their hair".(2)

They are socially and culturally removed from the actual condition and when they come in contact with it they find it grotesque. The new relief officer, Mr Singh is presented as an honest and sympathetic official, who does everything help the people. But it is not enough because the people are in this condition due to negligence, ignorance and insensitivity of the Government officials themselves. Also Singh wants to amend things but persuading those converts into agriculturists. The key issue in the story is deprivation of food such that village 
boys are willing to work at the relief camp solely for food and without wages. But the condition of the Kubha tribe hide in the forest is much worse. They can neither produce within the forest due to the harsh climate and arid terrain nor can they come out as they would be shot dead. Lack of nutrition has made them skinny and shorter in height. It is their undersized physique that makes them resemble a kid. Their demeanour might have changed but the resistance in their gesture make them seem ghost like.

The literate world has inherited a comprehensive body of knowledge from the pre-literate world of verbal communication. Later, many periods passed by without acknowledging the oral value or otherwise that had been reproduced in the forms of text in the elite literatures, still some are unaware of that, continuing the inheritance from verbal communication. They are none but tribes and it is the central idea which Mahasweta Devi rejuvenates through her stories. This compendium of oral tradition from whatever ultimate origin is practically universal in character both in time and space. Being subject to the skilled and the unskilled of those who pass down the tradition, oral literature has undergone continuous changes over the course of changing generations. These changes have significant effects on its functions and permanence as literary culture.

In every human civilization, the process of successful social transformation depends upon the creative needs of the new generations and their continuous effort to re-construct or recreate the wisdom of their ancestors, which inspires a greater sense of freedom, self-respect and dignity. Hence these stories by Devi demonstrates the idea that since the upper caste (in India they are upper class too) acquires their identity through ancestors and their orality, they have been unaware of that indigenous too have the same tradition. If they were aware, they would not have done this unacceptable oppression. Indigenous voice is like a mighty thunder. The 
suspicion arises in the mind of relief officer in Little Ones is a common example for elites consciousness "he had the impression that singing played a big role in the lives of adivasis. Now he hears their songs for himself. Continuous, like the lonely wailing of an old witch. They are singing to scare away the ghosts". (2, Little Ones)

The Subaltern Historians originally started as an Indian version of "History from below" approach of the west. They were also influenced by the British Marxist Historians. The last two decades of the twentieth century have witnessed the emergence of diverse themes within the subaltern historiographical School. It is important to note that Mahasweta Devi speaks not only about the marginalized, but, far more importantly, about the marginalized within the communities of the marginalized. Her voice does not simply ventriloquise the plight of those at the edges of civilization, but goes deeper to analyse and reflect upon how the power structures that engender marginalisation are replicated in the texture of the society of the marginal. Thus, Mahasweta's true concern is with a subalternity subsumed within a larger parameter of subalternity 


\section{Works Cited}

Biswas, Amrita. "Research Note on Subaltern Studies." Journal of Literature, Culture and Media studies 1.2 (2009): 200-204. Print.

Chattopadhyay, Debasish. "Frames of Marginalisation in Mahasweta Devi’s Outcast: Four Stories.” Diva-portal, 2008. Web. 22 Mar 2016.

Devi, Mahasweta. Bitter Soil. Trans. Ipsita Chanda. Calcutta: Seagull Books, 1998. Print.

Landry, Donna, and Gerald MacLean, ed. The Spivak Reader. London \& New York: Routledge, 1996. Print. 